\title{
Escatología y demonio en el discurso religioso de la Guadalajara decimonónica
}

\section{Eschatology and the Devil in the Religious Discourse of 19th-Century Guadalajara}

\author{
Roberto Aceves Ávila \\ El Colegio de Jalisco, México \\ ORCID: 0000-0002-5002-1817 \\ racevesa@hotmail.com
}

Resumen: Este artículo analiza el caso de las devociones religiosas y el discurso acerca de los últimos tiempos y la presencia del demonio entre los fieles católicos en Guadalajara, capital del estado de Jalisco, México. Mediante el análisis de fuentes primarias de archivo y secundarias impresas de la época se muestra cómo en el contexto de la secularización promovida por el Estado muchas de las devociones religiosas no sólo mantuvieron vigente su continuidad, sino que incluso en varios casos aumentaron su popularidad y sus expresiones durante el siglo XIX. Se propone que la continuidad y el fortalecimiento de las creencias en dicho periodo pueden ser explicados, entre otras razones, por la presencia creciente de un discurso escatológico promovido por la Iglesia católica que fomentó la devoción en los creyentes y su acercamiento a la religión, alentando la participación de los laicos dentro de las actividades de la Iglesia.

Palabras clave: escatología; demonio; Guadalajara; catolicismo; siglo XIx.

Abstract: This article analyzes the case of religious devotions and discourse about recent times and the presence of the devil among the Catholic faithful in Guadalajara, the capital of the State of Jalisco, Mexico. The analysis of printed primary archival and secondary sources of the time shows how, in the context of secularization promoted by the state, many religious devotions not only maintained their continuity, but in some cases actually increased 
their popularity and expressions during the 19th century. The continuity and strengthening of beliefs throughout the 19th century can be explained, among other reasons, by the growing presence of an eschatological discourse promoted by the Catholic Church that fostered believers' devotion and their approach to religion, encouraging the participation of lay persons in the Church's activities.

Key words: eschatology; the Devil; Guadalajara; catholicism; 19th century.

Fecha de recepción: 2 de marzo de 2016 Fecha de aceptación: 29 de junio de 2016

$\mathrm{U}$ no de los aspectos más fascinantes que plantea el estudio de las creencias y devociones religiosas, tanto en México como en el resto del mundo, en el periodo que va desde fines del siglo XVIII hasta principios del xx, es el tratar de entender la manera en que estas se transformaron y se mantuvieron vivas, en constante tensión entre la continuidad y el cambio, dentro de un entorno caracterizado por el anticlericalismo, la secularidad y la laicidad, en especial a partir de la segunda mitad del siglo xIx. ${ }^{1}$ Por lo general, al analizar la evolución de las creencias religiosas durante dicho periodo, la historiografía tradicional se centra en el discurso del cambio y la transformación, es decir, la manera en que dichas devociones y creencias tuvieron que adaptarse, transformarse o incluso desaparecer dentro del nuevo entorno político, económico y social que se generó al amparo de las discusiones sobre la modernidad. ${ }^{2}$ Sin embargo, dicha visión no presta suficiente atención al

${ }^{1}$ Con frecuencia, el siglo xix en su conjunto suele caracterizarse por el laicismo, la secularización y el anticlericalismo. Sin embargo, es necesario matizar esta afirmación y no abarcar todo el siglo con estas calificaciones. Trabajos recientes de autores como Jaime Olveda Legaspi (2016) y David Carbajal López (2014) plantean para México una visión distinta del periodo previo a la reforma, y Brian Connaughton (1992) señala que en Guadalajara hasta antes de la reforma "La Iglesia aun representaba un conducto clave en la continuidad ideológica de la sociedad mexicana de aquella época” (p. 42). Ciertamente existieron algunas voces que clamaban en contra de la religión, pero antes de la reforma no parecen haber logrado predominar. Había más alarma por el "jansenismo" y por el surgimiento de posibles herejías que por el ateísmo, y no menor era el temor al "regalismo", entendido como la mano reformista de un Estado confesional católico (que México continuó siendo hasta 1857) interesado en intervenir en la situación administrativa de la Iglesia. El autor de este artículo agradece al dictaminador anónimo del mismo por sus ideas y observaciones en este sentido.

${ }^{2}$ Entendemos a la modernidad como un conjunto de ideas y procesos que constituyeron el entorno ideológico dentro del cual tuvieron que desenvolverse y definir su papel

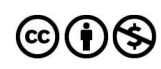


hecho de que muchas de las devociones religiosas, incluyendo aquellas consideradas como retrógradas o supersticiosas, no sólo mantuvieron vigente su continuidad, sino que incluso en muchos casos aumentaron su popularidad y sus expresiones. Tampoco trata de explicar las causas por las que se observó dicho fenómeno.

William B. Taylor (2010) ha señalado el hecho de que en el siglo xIX en México, tanto la Iglesia como la espiritualidad católica no desaparecen, sino que en muchos casos su papel parece fortalecerse, tanto en el ámbito político y social como en la devoción de los creyentes. Taylor ha señalado cómo, aun en épocas en las que predominan las ideas de secularización y laicidad, el fervor de los creyentes parece crecer, manifestándose en un mayor número de santuarios y devociones. A pesar de la creciente secularización de la sociedad, la fe pareció no disminuir, e incluso creció en intensidad emocional (Taylor, 2010, pp. 165-168). ¿Cómo explicar esta permanencia, continuidad e incluso fortalecimiento de las creencias y devociones a lo largo de un periodo tradicionalmente visto como secularizador?

Una de las explicaciones más utilizadas para ilustrar el fenómeno de la permanencia y continuidad de las creencias a lo largo del tiempo es el argumento del miedo. En momentos de necesidad los fieles suelen recurrir a diversas prácticas y devociones religiosas con el fin de ayudarse a sobrellevar las crisis. Esta solicitud de intervención divina en la vida de los fieles se orienta, por una parte, a evitar los peligros que atentan contra la salvación personal. Jean Delumeau (1997, pp. 24-26) ha señalado cómo nuestros antepasados recurrieron con frecuencia al uso de reliquias para luchar contra los peligros que amenazaban la vida de los individuos y las bestias, así como para apartar las amenazas de las potencias maléficas, y que a partir del siglo XVI tanto la Iglesia católica como la protestante se esforzaron por orientar

los diferentes actores sociales principalmente desde finales del siglo XVIII y hasta principios del siglo xx. Al describir el fenómeno de la modernidad en relación con los procesos de independencia en Latinoamérica, François-Xavier Guerra (1992) caracteriza a este como "un conjunto de mutaciones múltiples en el campo de las ideas, del imaginario, de los valores, de los comportamientos en parte comunes y en parte diferentes a las que llevaba consigo el absolutismo" y propone que la modernidad se distingue sobre todo por el individualismo, por el proceso mediante el cual el individuo es configurado, y se convierte en el "sujeto normativo de las instituciones" (p. 85). En este sentido, consideramos que la modernidad no es en estricto sentido un concepto científico bien definido, sino más bien un "indicador epistemológico" como los designa Foucault (1981, p. 152) en su debate con N. Chomsky, es decir, un concepto utilizado en diversas ciencias con funciones clasificadoras, delimitantes, que permite articular y situar a su alrededor un discurso y una serie de discusiones científicas, con el fin de generar nuevos conocimientos.

\section{()(1) $(3$}


cada vez más los rezos y las súplicas de los fieles hacia la preocupación por la salvación eterna, adicionalmente haciendo uso de las indulgencias como respuesta al temor suscitado en los católicos por el purgatorio.

Por otra parte, la intervención divina también fue, y aún es vista, como necesaria para asegurar el bienestar material y la seguridad personal de los creyentes. Anne Staples (2009) nos recuerda además que en México el miedo generado entre la población a consecuencia de los procesos de secularización de la sociedad entre 1821 y 1859 fue uno de los motores importantes del imaginario de la población a lo largo del siglo xıx.

\section{LA DEVOCIÓN COMO FORMA DE ENFRENTAR LOS MIEDOS: EL CASO DE GUADALAJARA, MÉXICO}

Al analizar el caso de Guadalajara, capital del estado de Jalisco en México, Jaime Olveda (1997) señala que cada época tiene sus propios miedos y angustias dentro de su imaginario colectivo, y las devociones religiosas fueron una manera común de enfrentarlos: "En la época colonial, la sociedad recurrió a muchos ritos apaciguadores, al empleo de reliquias y al culto de muchos santos para combatir el miedo, o para protegerse de los accidentes de las enfermedades y de otros peligros individuales y colectivos" (p. 14). Guadalajara adoptó varios patronos a lo largo del tiempo que la protegieran frente a diversas calamidades, como la elección de san Miguel Arcángel como defensor de la ciudad en septiembre de 1541, de san Clemente como patrono contra los rayos en agosto de 1591, de san Martín como patrono contra las hormigas en octubre de 1713, de la Virgen de Zapopan como patrona y abogada contra los rayos, epidemias y enfermedades en noviembre de 1734, de Nuestra Señora de la Soledad como patrona contra los terremotos en agosto de 1771, y nuevamente de la Virgen de Zapopan como patrona y generala de armas de la Nueva Galicia en agosto de 1821 (Martínez, 1992, p. 186).

Más adelante, a lo largo del siglo xix la Iglesia y los fieles de Guadalajara continuaron recurriendo a la religión para enfrentar una serie de males episódicos que se percibían como ocasionales y pasajeros, y que podían ser resueltos mediantes rogativas casuísticas a Dios o a sus santos. Por ejemplo, en 1847 el obispo Diego Aranda y Carpinteiro dirige una carta al prior del convento de San Agustín, en la que señala que la invasión estadunidense a México es castigo de Dios, y por ello pide celebrar a todos los párrocos un triduo a María Santísima de Guadalupe para remedio de este mal, cosa que

\section{()(1) $(2$}


también se debería hacer en todos los conventos. ${ }^{3}$ Por su parte el mismo obispo en el mismo año recibe peticiones de varias religiosas solicitando realizar diversas acciones, como festejos solemnes a santa María de Guadalupe "para implorar su intercesión por las necesidades de la patria" ${ }^{4}$ o bien solicitando al convento de Jesús María que "la imagen del Divino Preso sea llevada a Catedral y luego en procesión pública con plática para aplacar la ira de Nuestro Señor". ${ }^{5}$ Para la epidemia de cólera morbo de 1850 en San Juan de los Lagos y Tepatitlán los fieles dirigen varias cartas al obispo Diego Aranda y Carpinteiro solicitando que salga en procesión la imagen de la Virgen, pues señalan que "Creemos como tabla única de salvación es nuestra Divina Señora [...]. La Divina Señora expuesta en las calles purificará el ambiente" ${ }^{\text {y }}$ y que "el pueblo está conmovido. Ansía que llegue el momento para que salga Nuestra Señora. Su Santuario está todo el día lleno de gente, pidiéndole que nos socorra en el trance, que de un momento a otro todos esperamos, que es la muerte [...] que interceda ante su Hijo para que calme semejante epidemia.. ${ }^{7}$ Unos días después el obispo autoriza la procesión, y en respuesta se señala que "Ayer por la tarde salió la Sma. Virgen en procesión pública y desde aquello ha sido notable la calma y disminución de enfermos". ${ }^{8}$

En la última mitad del siglo xIx el arzobispo Pedro Loza también emitió diversas circulares y cartas como la del 22 de julio de 1875, en la que se solicitaba a los fieles "rezar la oración Pro témpore terremotus, para pedir que

${ }^{3}$ Carta del obispo Diego Aranda y Carpinteiro al Reverendo padre prior del convento de San Agustín. 17 de abril de 1847. Por un error de clasificación, dicha carta se incluye en Sección Gobierno. Serie Secretaría General. Cólera Morbus. Caja 1, 1833-1850. Archivo Histórico del Arzobispado de Guadalajara (en adelante AHAG), Guadalajara, México.

${ }^{4}$ Carta de sor Ma. Guadalupe de la Santa Cruz al obispo Diego Aranda y Carpinteiro. 21 de abril de 1847. Sección Gobierno. Serie Secretaría. Religiosos de Santo Domingo. Convento de Santa María de Gracia. Caja 15, años 1845-1854. AHAG, Guadalajara, México.

${ }^{5}$ Carta de sor Ma. Simona de San Agustín al obispo Diego Aranda y Carpinteiro. 21 de septiembre de 1847. Sección Gobierno. Serie Secretaría. Religiosos de Santo Domingo. Convento de Santa María de Gracia. Caja 15, años 1845-1854. AHAG, Guadalajara, México.

${ }^{6}$ Carta de Felipe Zermeño, cura de San Juan de los Lagos a Diego Aranda y Carpinteiro. 2 de enero de 1850. Sección Gobierno. Serie Secretaría General. Cólera Morbus. Caja 1, años 1833-1850. AHAG, Guadalajara, México.

${ }^{7}$ Carta de Juan Nepomuceno Márques a Diego Aranda y Carpinteiro. 9 de enero de 1850. Sección Gobierno. Serie Secretaría General. Cólera Morbus. Caja 1, años 1833-1850. AHAG, Guadalajara, México.

${ }^{8}$ Carta de Felipe Zermeño, cura de San Juan de los Lagos a Diego Aranda y Carpinteiro. 14 de enero de 1850. Sección Gobierno. Serie Secretaría General. Cólera Morbus. Caja 1, años 1833-1850. AHAG, Guadalajara, México.

\section{()(1) $\$$}


cese esa calamidad que azota a Guadalajara desde hace 5 meses"; 9 la del 23 de julio de 1875 en la que se anunciaba la "celebración del triduo a Nuestra Señora de la Soledad como patrona contra los terremotos"; la misa cantada, o al menos la oración Pro témpore terremotus en el Sagrario, el Santuario, la iglesia de Jesús, Analco y Mexicalcingo; ${ }^{10}$ y la del 29 de agosto de 1877 en la que se anunciaba un triduo en catedral para que Dios "aparte la calamidad de la sequía y la pérdida de cultivos". ${ }^{11}$

\section{LA CONFIGURACIÓN DEL DISCURSO ESCATOLÓGICO DE LA IGLESIA CATÓLICA EN EL SIGLO XIX}

El recurrir al auxilio de la religión católica y de sus santos fue un recurso habitual de los tapatíos para enfrentar sus miedos y solucionar las crisis periódicas que asolaban a la región y al país. Pero esta no fue la única manera en que la religión intervino en el imaginario de los habitantes. Desde fines del siglo xviri la Iglesia católica configuró un discurso de orden escatológico en el que el diablo tuvo una participación importante, y que ayudó a introducir en la mentalidad de los fieles la idea de que la condición de crisis que enfrentaban tanto la sociedad como la Iglesia católica no era una situación local, episódica y temporal, sino que era universal y permanente, producto de las crecientes condiciones de secularización y laicización que enfrentaba la sociedad y de una mayor presencia real del demonio en la historia. Consideramos que la continuidad e incluso el fortalecimiento en muchos casos de las creencias a lo largo del siglo xix puede ser explicado, entre otras razones, por la presencia creciente de este discurso religioso escatológico que fomentó la devoción en los creyentes y su acercamiento a la religión. Dicho discurso no sólo alentó y fomentó la participación de los laicos dentro de las

9 Circular del arzobispo Pedro Loza sobre la oración pro tempore terremotus. 22 de julio de 1875. Sección Gobierno. Serie Cartas pastorales. Edictos y circulares. Caja 9, años 18591883, exp. 91, ficha 598. AHAG, Guadalajara, México.

${ }^{10}$ Carta del arzobispo Pedro Loza a los curas de la arquidiócesis sobre la celebración de diversos actos piadosos para pedir contra los terremotos. 23 de julio de 1875. Sección Gobierno. Serie Cartas pastorales, edictos y circulares. Caja 9, años 1859-1883, exp. 91, ficha 598A. AHAG, Guadalajara, México.

${ }^{11}$ Circular del arzobispo Pedro Loza a los curas de la arquidiócesis sobre la celebración de un triduo en Catedral contra la sequía y pérdida de cultivos. 29 de agosto de 1877. Sección Gobierno. Serie Cartas pastorales, edictos y circulares. Caja 9, años 1859-1883, exp. 99, ficha 606. AHAG, Guadalajara, México.

\section{()(1) $\$$}


actividades de la Iglesia, sino que también ayudó a configurar en ellos una "espiritualidad política", es decir, una forma de vivir la práctica de su religión dentro de la sociedad y que tuvo consecuencias tanto políticas como sociales.

Esta visión escatológica de la sociedad, promovida por la Iglesia católica, principalmente a partir de la segunda mitad del siglo xIx, es una de las razones que nos permiten comprender por qué los fieles de Guadalajara no sólo conservaron muchas de las prácticas y devociones heredadas desde el periodo colonial aun en tiempos de anticlericalismo, secularización y laicidad, a pesar de los esfuerzos normativos de la Iglesia, el Estado y diversos sectores de la intelectualidad tapatía por configurar un creyente y una práctica religiosa más ilustrada. Los fieles no sólo conservaron sus viejas devociones, sino que además adoptaron otras nuevas de carácter más universal, como el culto a san José, y aumentaron su participación en la Vela perpetua y la Hora Santa, organizaciones dedicadas a la adoración del Sacramento. Proponemos que el temor y la incertidumbre generados por esta visión escatológica generaron en los fieles la necesidad de recurrir a y conservar sus prácticas religiosas tradicionales, como forma de enfrentar la incertidumbre y el temor ante lo que percibían como la inminente destrucción del orden social. Si la Iglesia mostró que el cambio social basado exclusivamente en el materialismo, el progreso y la razón llevaba a la ruina, los fieles decidieron aferrarse a la forma tradicional de practicar su religión, como una forma de enfrentar estas adversidades. Los fieles no trataron de sustituir sus viejas prácticas y devociones con nuevas ideas sobre ciencia y progreso, sino que en muchos casos todas estas ideas se complementaron en su visión del mundo, pues les resultaban útiles para enfrentar el miedo y la incertidumbre. Mantener sus prácticas tradicionales de culto y devoción fue lo que les permitió enfrentar sus temores y oponerse, de algún modo, al avance de las tendencias secularizadoras en la sociedad.

Mircea Eliade (1978) resume a grandes rasgos las características generales de los discursos milenaristas y escatológicos dentro del cristianismo señalando que bajo esta concepción

este mundo de aquí -el Mundo de la Historia- es injusto, abominable, demoníaco; felizmente ya está descomponiéndose, las catástrofes han comenzado, este viejo mundo se resquebraja por todos lados; en muy breve plazo será destruido, las fuerzas de las tinieblas serán vencidas definitivamente y "los buenos" triunfarán, el Paraíso será recobrado. Todos los movimientos milenaristas y escatológicos dan prueba de optimismo. Reaccionan frente al

\section{()(1) $(2$}


terror de la historia con una fuerza que sólo puede suscitar la extrema desesperación (p. 74).

Gabriel Cid (2014) ha señalado la importancia del discurso escatológico en la literatura religiosa producida en Iberoamérica a lo largo del siglo xIX:

La celeridad de los cambios políticos, sociales y culturales que produjo en el mundo hispánico la era de las revoluciones descolocó a muchos observadores católicos, quienes encontraron una fuente de explicación de estos fenómenos en un lente apocalíptico que permitía reconstruir la lógica y dinámica de estos procesos, puesto que, como sabemos, la escatología se caracteriza particularmente por su riqueza en la generación de significado. [...] Desde esta óptica de análisis, la lectura escatológica de los procesos de secularización y laicización poseía un valor fundamental para el mundo católico. Si, en efecto, el presente era sombrío y el futuro inmediato parecía tener al Anticristo como líder global de su imperio pagano, inmoral e irreligioso, la perspectiva escatológica cristiana permitía dotar a este presente adverso de un futuro glorioso, puesto que todos los textos coincidían que, a pesar que el signo de los tiempos era anticristiano, el final de la historia providencial era la parusía y la victoria final de la religión verdadera, que obviamente para ellos, era sólo la católica (pp. 200-2019).

Dentro de esta visión escatológica dos son los grandes protagonistas del discurso. En primer lugar, la Virgen María, en su advocación de la Inmaculada Concepción. La presencia de la Virgen María como participante activa en la historia de la defensa de la Iglesia se refuerza en 1854, cuando el papa Pío IX declaró a la Inmaculada Concepción como un dogma de fe. Unos cuantos años después, ocurren las apariciones y el llamado "Mensaje de Lourdes", o sea los gestos y las palabras que intercambiaron la Virgen y la vidente Bernardita Soubirous en la gruta de Massabielle, Francia, durante las 18 apariciones que ocurrieron del 11 de febrero al 16 de julio de 1858. Durante dichas apariciones la Virgen se identificó diciendo: "Soy Era Immaculada Councepciou" (Soy la Inmaculada Concepción), quien el 24 de febrero le había comunicado a Bernardita el mensaje: “¡Penitencia! ¡Penitencia! ¡Penitencia! ¡Ruega a Dios por los pecadores! ¡Besa la tierra en penitencia por los pecadores!”12

12 Para una descripción más detallada de los mensajes y las apariciones véase la página web oficial del sitio del santuario de Nuestra Señora de Lourdes, http://es.lourdes-france.

\section{()(1) $(3$}


Esta irrupción de la visión de la Virgen como actriz central dentro del desarrollo de la historia moderna pone de relieve el ambiente escatológico en que se mueve la Iglesia católica en dicha época. Las apariciones de la Virgen son una señal de que Dios no ha dejado sola a su Iglesia para enfrentar los ataques de que es objeto. Después de las revoluciones de 1789 y de 1848, Europa entró en un periodo de convulsión política que puso en entredicho el orden político y social establecido en Francia, Prusia, Países Bajos, Rusia y los reinos de la península itálica. Las monarquías tradicionales y el papado fueron cuestionados, y las elites gobernantes junto con la Iglesia comenzaron a sentirse bajo ataque permanente, no sólo de fuerzas materiales y sociales, sino también de fuerzas sobrenaturales que trataban de destruir al catolicismo y socavar el orden social establecido. Este es un elemento muy importante que se debe entender al analizar las devociones religiosas de la época, pues el miedo y la visión milenarista que de él emanan nos explican por una parte las razones por las que la Iglesia patrocinó ciertos cultos y devociones, y por otra la forma en que los fieles las entendieron y adoptaron.

En el caso de Guadalajara, la promoción de los cultos marianos, especialmente los relacionados con la Inmaculada Concepción, también se fortalecerá a partir de la segunda mitad del siglo xIx. El obispo Pedro Espinosa y Dávalos, a quien tocó celebrar en 1855 en Guadalajara la declaración dogmática de la Inmaculada Concepción, promovió y defendió el culto a la Virgen de Zapopan (cuya advocación original era precisamente el de la Inmaculada Concepción), junto con sus manifestaciones públicas, quizá como una forma de oponerse a las restricciones impuestas por las Leyes de Reforma, mientras que el arzobispo Pedro Loza manifestó una abierta predilección por el culto a la Virgen de Guadalupe, otra advocación de la Inmaculada, relacionada con la visión nacionalista opuesta al protestantismo que defendía la Iglesia de la época. Asimismo promovió también la devoción franciscana a la Virgen del Refugio, así como la práctica del rezo del rosario y la devoción a la virgen del mismo nombre.

Además de la Virgen, el otro gran protagonista de la visión escatológica de los fieles del siglo xix es el Diablo. Jacques Lafaye (2013) ha señalado con gran perspicacia la importancia del demonio en las concepciones

org/ Debe recalcarse que el concepto de la Inmaculada Concepción como protectora frente al demonio se inspira en la idea de que la Inmaculada es una representación de la mujer joven embarazada, vestida de sol, con la luna a sus pies y coronada de estrellas, que vence al dragón, y que aparece en el Apocalipsis 12:1-17.

\section{()(1) $\$$}


de la historia universal dentro de la tradición cristiana. Menciona que "Los altibajos de la imagen del Diablo en la historia del Occidente cristiano son un barómetro de la conciencia colectiva, cuando menos desde la muerte de Jesucristo hasta el nacimiento de Nietzsche, o mejor dicho de su ensayo Más allá del bien y del mal, de 1886, esto es cerca de dos milenios" (p. 59). Jean Delumeau (2012) plantea que contrariamente a lo que muchos creyeron, fue al principio de los tiempos modernos y no en la Edad Media cuando "el infierno, sus habitantes y sus secuaces acapararon más la imaginación de los hombres de Occidente" (p. 301). En efecto, en el caso de Occidente, en el siglo XIX el demonio reaparece con fuerza en muchas explicaciones históricas, ${ }^{13}$ ante la percepción colectiva de que las instituciones políticas y religiosas se encuentran bajo su ataque. Ya desde 1797 el pensador Joseph de Maistre, una de las figuras centrales del pensamiento de la reacción en Occidente, había expuesto en su ensayo Considérations Sur la France la influencia del Diablo en la revolución francesa. Maistre (2003) hacía notar esta presencia diabólica en el surgimiento de planteamientos antirreligiosos que dejan de reconocer a Dios como elemento central de todo gobierno, idea que sirvió de modelo a análisis posteriores que se hicieron de otras revoluciones:

Lo que distingue a la Revolución Francesa y la hace un evento único en la historia es que es radicalmente mala. No hay un elemento de bien que distraiga el ojo del observador; es el más alto grado de corrupción jamás conocido; es la pura impureza. [...] En particular, si consideramos los actos de la Asamblea Nacional, es difícil encontrar algo que aprobar. Cuando recuerdo su reunión, me siento transportado [...] a un mundo imaginario; veo al enemigo de la humanidad [...] convocando a cada espíritu maligno a este nuevo pandemónium; [...] Hay una cualidad satánica en la Revolución Francesa que la distingue de todo lo que hemos visto o de todo lo que posiblemente veremos en el futuro. [...] Todo esto va más allá del círculo ordinario del crimen y parece pertenecer a otro mundo. [...] La mera omisión (ya no digamos rechazo) del gran Ser de toda empresa humana la marca con un irrevocable anatema (Maistre, 2003, pp. 38-41).

${ }^{13}$ Delumeau (2012) señala por ejemplo que desde el siglo xvi no sólo la Iglesia católica, sino también Martín Lutero habían asociado a los turcos y a los judíos con el diablo, y Lutero incluso los asocia con el papado, unidos en una "alianza objetiva entre unos y otros -complot satánico que ataca al mundo cristiano debilitado y pecador a la vez [...]" (p. 337). Asimismo Lutero llama a los judíos "hijos del diablo", y a Satán "inspirador del papa y general de los turcos" (p. 354).

\section{()(1) $\$$}


Estas ideas fueron retomadas por varios escritores católicos, quienes vieron todas estos eventos (laicización del Estado y sus instituciones, culto a la razón, replanteamiento del papel de la Iglesia en la sociedad civil, entre otras) como señales inequívocas del fin de los tiempos.

Este discurso escatológico del que venimos hablando tiene dos vertientes: una personal, en la que se busca combatir al demonio como generador de tentaciones y causante de la condenación individual de los fieles. Esta vertiente es la que se ve reflejada en diversos discursos y sermones de la época que tratan esencialmente de la reforma de las costumbres y la moral para lograr la salvación de los creyentes y combatir a los tradicionales enemigos del alma que señala el catecismo: mundo, demonio y carne. Pero existe además otra vertiente, la social, en la que el demonio es el causante de la decadencia de la sociedad a través de su influencia mediante organizaciones como la masonería y otras sectas, que promueven la irreligiosidad, la impiedad, la demagogia y con ello la pérdida del respeto a la autoridad establecida. Esta visión tiene importantes implicaciones políticas, pues invita al creyente a adoptar, mediante el ejercicio de su creencia, una posición de combate y resistencia frente a aquellas posturas ideológicas que minan la viabilidad del orden social. En México, el realizar acciones concretas, como el pertenecer a obras pías vinculadas a devociones universales, como la Vela Perpetua para mujeres (dedicada al culto del Sacramento), o ayudar a los frailes exclaustrados a raíz de la reforma, debió ser visto por muchos católicos como una forma de oposición a una postura política anticlerical que se consideraba errónea. Esta vertiente del discurso escatológico fue promovida por diversas autoridades eclesiásticas y fue compartida por diversos sectores conservadores, tanto laicos como religiosos. En este sentido es interesante consultar el folleto Crímenes de la demagogia. El Colegio Apostólico en Zacatecas, impreso en Guadalajara en 1859 y reimpreso varias veces en México los siguientes años. Apareció bajo el seudónimo de "Un Católico", que corresponde al coronel y posteriormente general conservador Remigio Tovar. En dicho folleto se contiene una descripción somera de la forma en que los habitantes de Zacatecas veían a su convento de Guadalupe y a sus moradores antes de la expropiación del mismo como consecuencia en 1859 de la emisión de la Ley de Nacionalización de los Bienes del Clero Secular y Regular por el gobierno liberal. Dicho folleto nos muestra un ejemplo concreto de cómo el lenguaje escatológico permea en la visión de un conservador, que ve en el ataque a los institutos monásticos y en la desaparición de esta comunidad un indicio

\section{()(1) $(3$}


del fin de la sociedad civilizada, gracias a la demagogia liberal. El autor del folleto (Tovar, 1859) señala:

He aquí la demagojia [sic] de nuestros días. Allá en otra época, a pretesto [sic] de una idea grande, se inoculó un germen de disolución en nuestra sociedad; [...] En cuanto a los hombres; en cuanto a los héroes propagandistas de ese sistema de ideas infernales, poco nos cuidamos de ellos, son demasiado pequeños, para que se les haga el honor de juzgarles capaces de una gran cosa, ni aun en el mal. Ogazón y Rocha, Rojas y Juárez, Iniestra y Pueblita, son espumas impuras que se han levantado a la superficie del Océano, conmovido por los furores del oraje: [...] pero no son ellos la enfermedad misma, sino síntomas de una infición general en todo el sistema; infición anterior, y que se ha esplicado [sic] por tales o cuales asquerosos fenómenos. Estos son los hombres de la demagojia [sic] actual” (pp. 64-65).

Este es tan sólo un ejemplo de cómo en México la visión escatológica de la sociedad se vio alentada no sólo desde la perspectiva institucional de la Iglesia, sino también desde la óptica individual de los fieles. Un elemento importante dentro del imaginario social religioso del siglo xIx en México y en Jalisco fueron también las llamadas profecías de la llamada Madre Matiana, que como señala Wright-Rios $(2014$, p. 9) fue una sirvienta iletrada del convento de San Jerónimo de la ciudad de México que vivó entre mediados del siglo xviı y la primera mitad del xix, y cuyo nombre era Matiana del Espíritu Santo. Nunca profesó como monja. Sin embargo, durante el gobierno del arzobispo Alonso Núñez de Peralta (1772-1800) comenzó a experimentar momentos de rapto espiritual en los que la Virgen María le permitió a Matiana tener visiones sobre una conspiración satánica destinada a destruir la cristiandad católica. ${ }^{14}$ Edward Wright-Rios (2014, p. 228) ha señalado la im-

${ }^{14}$ Para una historia de Matiana, sus visiones y la manera en que estas fueron rescatadas y publicadas, véase Velasco Toro (2007). Las visiones de Matiana se publicaron por vez primera en México en calendarios populares, primero en 1847, y posteriormente en 1857 en el Calendario nigromántico para 1858 y en 1866 en el Calendario de la Madre Matiana para el año de 1867. En 1889, en la ciudad de México Luis G. Duarte publicó una versión comentada de las mismas, con el título Profecías de Matiana acerca del triunfo de la iglesia expurgadas, defendidas y corroboradas con respetabilísimos y muy notables vaticinios de santos, de personas canónicamente beatificadas y de otras que han muerto en olor de santidad. Dicha obra se publicó con las debidas licencias eclesiásticas y fue dedicada al arzobispo de México Pelagio Antonio de Labastida y Dávalos. En 1914, en la ciudad de México se publicó un nuevo folleto anunciándolo como Las verdaderas profecías de Matiana comparadas y coordinadas con otras profecías semejantes de este y

\section{()(1) $(3$}


portancia de este tipo de escritos para el estudio de la religiosidad femenina en México, y señala que el legado de Matiana fue una influencia importante en el imaginario religioso de la población en México. De hecho, en Jalisco esta influencia se extendió hasta el siglo xx, cuando Agustín Yáñez hizo de Matiana un personaje de una de sus novelas jaliscienses, Las tierras flacas, de 1962. Las visiones de Matiana publicadas en el Calendario nigromántico para el año 1858 (1857) incluyen un componente fuertemente escatológico en el que el demonio desempeña un papel central:

Vio también un conciliábulo en el Infierno, y el tormento que padecían los demonios por la paz, la copia [sic] que reina en los cristianos en su tiempo, principalmente en el de Lucifer. Entraron ellos en congreso, y entre todos hicieron la constitución y el código, y que Lucifer mandó a los demonios estendieran [sic] estas constituciones por todo el mundo, para pervertir a todos y que se vació el infierno para guerrear con los cristianos, y que aun en los animales se metían: embistiendo a los buenos y no a los malos (pp. 36-37).

Matiana predijo entre otros eventos la secularización de los conventos, junto con otras múltiples persecuciones para la Iglesia y desgracias para la sociedad. A partir de la exclaustración ordenada por las Leyes de Reforma muchos religiosos de Guadalajara, en especial los franciscanos expulsados de los conventos de Propaganda Fide de Zapopan y de Guadalupe de Zacatecas, encontraron apoyo y resguardo en las sociedades locales. Es probable que los fieles hayan visto en la exclaustración una confirmación de las predicciones escatológicas del fin de los tiempos, preconizadas por las visiones de la Madre Matiana y el discurso milenarista de la Iglesia.

Los embates del racionalismo contra la ideología religiosa, la laicización de los Estados, la secularización de la sociedad, la proliferación de "sociedades secretas" como la masonería e ideologías como el socialismo, el surgimiento de nuevas herejías junto con el avance del protestantismo, y la pérdida del poder temporal e influencia de la Iglesia seguramente fueron vistos como aspectos de un mismo fenómeno: el ataque, por parte de las fuerzas del mal y específicamente del demonio, en contra de la Iglesia y del orden social establecidos por Dios. Por ello la Iglesia requirió confirmar su posición ideológica y su postura frente a los ataques de que era objeto, y convocó

del antiguo continente acerca del triunfo final de la iglesia y del fin del mundo (Velasco Toro, 2007, pp. 41-42).

\section{()(1) $(9$}


en 1867 a la celebración del Concilio Vaticano I, en el que se definieron la institución del primado en Pedro, la perpetuidad del primado de Pedro en el romano pontífice, la naturaleza de dicho primado, así como el dogma de la infalibilidad papal en materia de magisterio doctrinal, mediante la bula Pastor Aeternus.

En el proemio de la constitución dogmática Pastor Aeternus del 18 de julio de 1870, cuyo texto puede consultarse en Collantes (2009), se señala expresamente la acción del demonio en contra de la Iglesia, y la necesidad de fortalecer la doctrina de la primacía del papado como forma de combatir dicha influencia:

Y como la potencia del infierno se levanta por todas partes con odio creciente contra el fundamento divino de la Iglesia, para derribarla si pudieran, Nos juzgamos ser necesario para la defensa, incolumidad y aumento de la grey católica, con la aprobación del santo concilio, proponer a todos los fieles la doctrina que deben creer y mantener firmemente acerca de la institución, perpetuidad y naturaleza del primado de la santa Sede Apostólica, sobre el que descansa la fuerza y solidez de toda la Iglesia, [...] y a la vez proscribir y condenar los errores contrarios, tan perniciosos para el rebaño del Señor (p. 471).

La misma visión escatológica de la situación social vuelve a aparecer más adelante en la segunda encíclica emitida por el papa León XIII, Quod Apostolici Muneris del 28 de diciembre de 1878 (Colección, 1879, pp. 249-260). Dicha encíclica constituye un ataque contra el socialismo, el comunismo, el nihilismo, la masonería y otros errores, con un lenguaje que prefigura con claridad la lucha entre el bien y el mal. En dicha encíclica no sólo se denuncian estas doctrinas, sino que también se proponen remedios contra ellas. De hecho, la encíclica fue traducida al español y publicada en Guadalajara en 1879 "por disposición de la Superioridad Eclesiástica” y, como veremos más adelante, influyó en las decisiones de impulsar varias devociones para combatir los males que propagaban estas ideas.

Desde nuestro advenimiento al Pontificado [...] no hemos cesado en las Letras Encíclicas que os hemos dirigido [...] de mostrar la peste mortal que se inocula en los miembros íntimos de la sociedad humana, poniéndola en el más inminente de los peligros. [...] aludimos a esta secta de hombres, que bajo nombres diversos y casi bárbaros, se denominan socialistas; comunistas

\section{()(1)(3)}


o nihilistas, y que esparcidos en el mundo entero, y estrechamente ligados entre sí por, un vínculo de iniquidad; ya no se recatan al abrigo de las tinieblas de conciliábulos secretos, sino que se muestran llenos de confianza a toda luz, y se esfuerzan en llevar a término el designio formado desde hace largo tiempo de trastornar los fundamentos de toda sociedad civil (Colección, 1879, p. 249).

León XIII pone de relieve el hecho de que estas doctrinas malignas ponen en riesgo al orden político y social establecido, pues al no reconocer la autoridad pública como fuente a Dios, se corre el riesgo de que los dirigentes se sientan libres de la sanción divina y no se sometan a más leyes que las civiles. Con ello aparece un nuevo riesgo derivado de una mayor libertad de pensamiento y acción: el que las masas proletarias se rebelen y busquen trastocar el orden establecido de la sociedad:

Difundidas ampliamente estas doctrinas por donde quiera, e introducidas en todas partes esta exagerada licencia de pensamiento y acción, no debe sorprender que los hombres de condición más ínfima, cansados de la pobreza y del encierro en su estrecho taller, ardan en deseos de invadir los palacios y la fortuna de los ricos, tampoco debe sorprender que vaya desapareciendo la tranquilidad de la vida pública y privada, ni que el género humano casi toque el borde del abismo. [...] Y como se buscan, sobre todo, sectarios del socialismo en la clase de los que ejercen oficios mecánicos, o que viven, del salario por su trabajo, y que cansados de la condición de obreros, son fáciles de seducir con la esperanza de la riqueza y las promesas de la fortuna, parece oportuno sostener a las sociedades de artesanos y de trabajadores, que fundadas bajo la tutela de la Religión, enseñan a todos los asociados a contentarse con su suerte a sobrellevar el trabajo con paciencia, y les persuaden a vivir en calma y tranquilidad (Colección, 1879, pp. 251 y 260).

En el último párrafo citado se destaca una de las soluciones propuestas contra los males de estas doctrinas perniciosas: la promoción de sociedades de artesanos y trabajadores junto con las devociones a ellas asociadas, de carácter universal, como serán las asociaciones josefinas, dedicadas al culto perpetuo de san José, patrono universal de la Iglesia y de los obreros. La encíclica cierra invocando la protección de la Inmaculada Virgen María, de san José su esposo, y de san Pedro y san Pablo, todos ellos protectores de la Iglesia universal.

\section{()(1) $(3$}


Unos años más tarde, en la encíclica Humanum genus del 20 de abril de 1884 en contra de la masonería y otras sectas, que también fue reimpresa en Guadalajara (Colección, 1886, pp. 301-335), vuelve a aparecer con más claridad y fuerza la visión escatológica de la historia, en la que el mundo está dividido en dos bandos contrapuestos que luchan entre sí, en uno de los cuales participan los masones liderados por el demonio. Así, León XIII comienza dicha encíclica diciendo:

El humano linaje, después que, por envidia del demonio, se hubo, para su mayor desgracia, separado de Dios, creador y dador de los bienes celestiales, quedó dividido en dos bandos diversos y adversos: uno de ellos combate asiduamente por la verdad y la virtud, y el otro por todo cuanto es contrario a la virtud y a la verdad. El uno es el reino de Dios en la tierra, es decir, la verdadera Iglesia de Jesucristo, a la cual quien quisiere estar adherido de corazón y según conviene para la salvación, necesita servir a Dios y a su unigénito Hijo con todo su entendimiento y toda su voluntad; el otro es el reino de Satanás, bajo cuyo imperio y potestad se encuentran todos los que, siguiendo los funestos ejemplos de su caudillo y de nuestros primeros padres, rehúsan obedecer a la ley divina y eterna, y obran sin cesar o como si Dios no existiera o positivamente contra Dios. [...] En nuestros días, todos los que favorecen la peor parte parecen conspirar a una y pelear con la mayor vehemencia, bajo la guía y auxilio de la sociedad que llaman de los Masones [...] (Colección, 1886, pp. 301-302).

Que el Diablo está detrás de los masones e incluso presida sus reuniones es una idea que ya estaba presente en el imaginario de la Iglesia de Guadalajara y que se expresa de manera abierta en una nota publicada en dos partes el 8 y el 22 de diciembre de 1880 en el tomo in de la Colección de documentos eclesiásticos publicada por la Arquidiócesis de Guadalajara. Dicha nota, publicada en 1880 por Un Amigo de la Verdad (1882, pp. 107-108) intitulada "El Diablo y los masones", reproduce un artículo publicado en la Semaine Religieuse de Grenoble, ${ }^{15}$ va precedida de una breve introducción que señala que este "tiene todos los caracteres de autenticidad" y que prueba con datos que "la influencia diabólica es hoy frecuente en el mundo corrompido, que sólo a ella pueden atribuirse esas sacrílegas profanaciones de los templos cuando

15 Se trata de la publicación La Semaine Religieuse du Diocèse de Grenoble, órgano oficial regular de la diócesis del mismo nombre, fundado por el obispo Jacques Ginoulhiac en 1868.

\section{(ㅇ)(1) $(3$}


no tienen un objeto práctico" y que "sólo por esta influencia satánica puede explicarse la horrenda ingratitud del hombre" contra sacerdotes, monjas y hermanas de la caridad. En la nota se relata el caso del padre dominico Jandel que a la salida de la catedral es abordado por un individuo misterioso que lo cuestiona sobre la validez de sus creencias y lo invita a participar en una reunión de francmasones presidida por el demonio con el fin de comprobar si la señal de la cruz es efectiva contra él. Después de consultarlo con su obispo, monseñor Bonald, el padre Jandel asiste a dicha reunión, y al hacer la señal de la cruz el demonio que preside la reunión desaparece entre humo y confusión, y el masón que hizo la invitación acaba por convertirse a la verdadera religión (Un Amigo de la Verdad, 1882, pp. 117-118).

A partir de finales de la década de 1870, en especial después de que se publican estas encíclicas Quod apostolici muneris de 1878 contra la masonería y el socialismo, y la Humanum genus de 1884 en contra de la masonería y otras sectas, la Iglesia reforzó su idea de una visión escatológica de la historia en la que esta y los creyentes se enfrentan con las fuerzas del mal, ahora encarnadas en las sectas masónicas y el socialismo. Si bien desde principios del siglo XIX (marzo de 1825) el papa León XII había publicado una bula que prohibía las sociedades secretas, entre ellas la francmasonería, y que se reimprimió en México unos años más tarde (León XII, 1839), es a partir de dichas encíclicas, y en especial de la Humanum genus, que la Iglesia plantea una propuesta de acción espiritual y social mediante la cual la sociedad pueda combatir a dichas fuerzas malignas a través de la realización de tres acciones: el fomento a la educación religiosa, el fortalecimiento de la orden de terceros franciscanos (que incluye a laicos dentro de su organización), y la mayor vinculación de la Iglesia con organizaciones religiosas de beneficencia laicas, como las Conferencias de San Vicente de Paul, que se encarguen de llevar a cabo obras pías y misericordiosas asociadas con devociones religiosas universales que sirvan de freno a los embates de la masonería y el socialismo y combatan de manera práctica y efectiva los males sociales (como la pobreza, la enfermedad y el desamparo de los más necesitados) que las organizaciones sin asociación religiosa pretenden corregir sin el auxilio de la fe y de la misericordia. Así, en estas encíclicas, la Iglesia reconoce de manera implícita que no puede combatir de manera efectiva los ataques del pensamiento liberal sin el apoyo activo de las instituciones laicas, y establece estrategias concretas para interactuar con dichas organizaciones. En especial, la encíclica Humanum genus (Colección, 1886 , p. 327) precisa la solución que en opinión del papado se requiere para mejorar la sociedad y combatir a las sectas, señalando que la mejor y más

\section{()(1) $(3$}


firme esperanza de remedio está puesta en la virtud de la religión divina, "tanto más odiada por los Masones cuanto más temida, consiste la mejor y más fundada esperanza de eficaz remedio".

El ataque a los principios morales y religiosos del catolicismo así como el promover el abandono de los deberes religiosos del Estado, junto con los principios de igualdad absoluta de los individuos y los de revolución contra la autoridad establecida tiene, de acuerdo con estas encíclicas, implicaciones políticas, pues con estas acciones se socava la gobernabilidad de la sociedad civil. Por ello se requiere combatir a las sectas promoviendo la piedad y la caridad a través de organizaciones laicas de orientación religiosa, y así lograr la salvación de los individuos y de la sociedad.

\section{DISCURSO ESCATOLÓGICO Y RELIGIOSIDAD TAPATÍA EN LA SEGUNDA MITAD DEL SIGLO XIX}

Es en este contexto inmerso en una visión escatológica de la historia que se debe analizar el crecimiento en Guadalajara a lo largo del siglo xix de sociedades como la de la Vela Perpetua (organización laica para mujeres dedicada al culto del Sacramento) a partir de la década de 1840, las Conferencias de San Vicente de Paul (organización benéfica que llegó a Guadalajara en 1853) y las asociaciones al culto perpetuo del Señor San José (patrono universal de la Iglesia) a partir de 1890. Posteriormente, el mismo León XIII promulgó el 25 de mayo de 1899 la encíclica Annum Sacrum, en la que recomienda la práctica de la devoción al Sagrado Corazón como una forma de luchar contra la impiedad. Asimismo, frente a todas estas amenazas del demonio consideradas como permanentes, y no sólo como ocasionales, la Iglesia propuso también otras medidas, entre las que se encontraban la promoción de diversas devociones universales, en especial las relacionadas con el Sagrado Corazón de Jesús y el culto a la Virgen María en sus diversas advocaciones.

La devoción del rosario fue otro importante instrumento universal de fomento a la piedad católica que se vio favorecida por la predilección que sentía León XIII por la misma. Esta devoción tenía varias ventajas, pues remitía dicha práctica al ámbito de los templos y los hogares, con lo que se evitaban muestras excesivas y públicas de piedad, ajustándose a los criterios de una religión ilustrada que procuraban tanto los liberales católicos como los conservadores progresistas en el entorno de la prohibición de las manifestaciones públicas del culto ordenadas por las Leyes de Reforma. Por otra

\section{(1)(1)}


parte, dicha devoción aprovechaba las posibilidades de instrucción religiosa y fomento de la piedad que se podían generar desde el interior de las familias, permitiéndole a la Iglesia intervenir aunque fuera de manera indirecta en el ámbito privado de la práctica religiosa.

En agosto de 1885, ante la situación política que enfrenta el papa (este se encuentra discutiendo con varios Estados europeos la firma de un nuevo Concordato) y ante la percepción de persecución que en general vive la Iglesia, León XIII ordena y decreta que desde el primero de octubre hasta el 2 de noviembre de cada año se recen todos los días al menos cinco dieces o misterios del rosario con las letanías lauretanas en todos los templos parroquiales del orbe católico, en todos los oratorios públicos dedicados a la Virgen y en aquellos templos que designe el ordinario, procurando que se realice la exposición del Santísimo. Señala que lo anterior debe perdurar "mientras dure este tristísimo estado de cosas, tanto para la Iglesia como para la sociedad civil, y mientras no sea concedido a la misma Iglesia el dar las gracias a Dios por el restablecimiento de la libertad plena para el Romano Pontífice". ${ }^{16}$ También desea que las asociaciones o congregaciones del Santísimo Rosario celebren con magnificencia religiosa las solemnidades públicas donde las leyes lo permitan. Para ello se conceden indulgencias de siete años y siete cuarentenas a aquellos fieles que asistan en los días determinados al rezo público.

En julio de 1886, mediante pastoral del 29 de junio del mismo año, el arzobispo de Guadalajara, Pedro Loza, anuncia el jubileo extraordinario universal convocado por el papa y que durará hasta diciembre del mismo año, señalando que "no cabe duda que la oración es la misteriosa arma que el señor ha puesto en manos de su santa Iglesia y de los cristianos todos para librarse de las asechanzas del enemigo común, para extirpar el error, para vencer el poder de Satanás, y para alcanzar del cielo las divinas gracias". ${ }^{17}$ Para celebrar el jubileo se pide a los fieles confesarse, comulgar, realizar dos días de ayuno con abstinencia de carnes, dar una limosna, y visitar seis veces

${ }^{16}$ Circular de Pedro Loza a los curas del arzobispado sobre la necesidad de rezar el Santo Rosario por las necesidades de la Iglesia. 24 de octubre de 1885. Sección Gobierno. Serie Cartas pastorales, edictos y circulares. Circulares, años 1884-1903, caja 10, exp. 12, ficha 649. AHAG, Guadalajara, México.

${ }^{17}$ Circular de Pedro Loza a los curas del arzobispado sobre el Jubileo extraordinario de 1886. 19 de octubre de 1886. Sección Gobierno. Serie Cartas pastorales, edictos y circulares. Circulares, años 1884-1903, caja 10, exp. 15, ficha 659. AHAG, Guadalajara, México.

\section{()(1) $\$$}


El Sagrario, así como las iglesias de Nuestra Señora de Guadalupe y Nuestra Señora de la Merced, haciendo oración por las intenciones del papa. ${ }^{18}$

El 21 de septiembre de 1888 Loza emite una nueva circular en la que, una vez más, se confirman las disposiciones relativas a la solemnidad del rosario durante el mes de octubre que se habían establecido en 1883 y 1884 , y se exhorta a los fieles a rezarlo diariamente. Asimismo, nuevamente vuelve a aparecer el lenguaje escatológico en dicha circular, asociado con el culto a la Virgen:

Desgarrador es el espectáculo que en la actualidad presentan las sociedades, hundiéndose como están en el abismo de la iniquidad, debido al formidable esfuerzo con que los malos, como instrumentos de Satanás, procuran derribar, si fuera posible, la Iglesia, y destruir y aniquilar todo orden y todo bien. Pidamos pues, mucho a Ntro. Señor el remedio de tantos y tan graves males, uniendo nuestras oraciones a las de la Santa Iglesia, sujetándonos a la forma que ella misma prescribe; [...]. ${ }^{19}$

El 14 de septiembre de 1889 Loza pide a los sacerdotes que de nuevo den a conocer a los fieles todas las disposiciones e indulgencias relacionadas con la celebración del mes del Santísimo Rosario, establecidas en 1883 y 1884 , y termina diciendo que "lo mismo que se practicó en 83 , se practicará en el presente año y en lo sucesivo, mientras no se disponga otra cosa”. ${ }^{20}$ Estas disposiciones se mantuvieron vigentes durante el arzobispado de Pedro Loza. Unos días después Loza lanza la que quizá es la última disposición importante que sobre este tema emitió durante su gobierno. El 20 de septiembre de 1889 confirma las disposiciones de la circular del pasado día 14, pero además, gracias a una encíclica de León XIII, se prescribe que se implore el auxilio de

${ }^{18}$ Circular de Pedro Loza sobre advertencias interesantes a los fieles acerca del Jubileo del presente año. 29 de junio de 1886. Sección Gobierno. Serie Cartas pastorales, edictos y circulares. Circulares, años 1884-1903, caja 10, exp. 17, ficha 654. AHAG, Guadalajara, México.

${ }^{19}$ Circular de Pedro Loza a los curas del arzobispado sobre la renovación de las disposiciones sobre la celebración del Santo Rosario. 21 de septiembre de 1888. Sección Gobierno. Serie Cartas pastorales, edictos y circulares. Circulares, años 1884-1903, caja 10, exp. 30, ficha 667. AнAg, Guadalajara, México.

20 Circular de Pedro Loza a los curas del arzobispado sobre la necesidad de dar a conocer a los fieles las indulgencias y disposiciones sobre la celebración del mes del Santo Rosario, instituida en 1883 y 1884. 14 de septiembre de 1889. Sección Gobierno. Serie Cartas pastorales, edictos y circulares. Circulares, años 1884-1903, caja 10, exp. 40, ficha 676. AHAG, Guadalajara, México.

\section{()(1) $(3$}


san José en los años siguientes. Por ello Loza dispone que después del rosario se diga dicha oración a san José, no solamente por el mes de octubre de este año, sino también en lo sucesivo. ${ }^{21}$

\section{LA ORACIÓN A SAN MIGUEL ARCÁNGEL Y LAS VISIONES INFERNALES DE LEÓN XIII}

Para apreciar el significado de estas devociones es necesario comprender que desde la perspectiva de la Iglesia los males sociales no tienen únicamente una raíz material, sino también metafísica, y por lo tanto también deben ser combatidos con medios sobrenaturales. A partir de la segunda mitad del siglo xIx la estrategia de la Iglesia no consiste sólo en recuperar su papel dominante dentro de la sociedad, o en configurar un feligrés moderno e ilustrado, acorde con los tiempos modernos. También promueve nuevas devociones de carácter social y universal encaminadas a promover el acercamiento de la clase obrera a la religión y combatir la impiedad y el avance de las fuerzas del mal en la sociedad a través de la educación y la dedicación a nuevas devociones. Este cambio en la estrategia de la Iglesia se ve acompañado por una serie de visiones y revelaciones sobrenaturales que hacen que a partir de la segunda mitad del siglo xIX se empiecen a rezar oraciones especiales por las grandes intenciones de la Iglesia, en las que debe participar también el pueblo, y que se rezan con los fieles en su propia lengua.

En 1886 León XIII introdujo una nueva fórmula de exorcismo y la invocación de san Miguel arcángel contra la amenaza del demonio, como consecuencia de una revelación sobrenatural. Hasta antes de las reformas del Concilio Vaticano II, por disposición de León XIII, el sacerdote y los fieles se arrodillaban al final de cada misa y dedicaban a san Miguel y a la Virgen la siguiente oración: "San Miguel Arcángel, defiéndenos en la lucha; contra la maldad e insidias del demonio sé nuestra ayuda. Te rogamos suplicantes; ¡que el Señor ejerza sobre él su poder! Y tú, príncipe de la milicia celeste, con la fuerza que Dios te ha conferido, arroja al infierno a Satanás y a los demás espíritus malignos que vagan por el mundo para perdición de las almas."

${ }^{21}$ Circular de Pedro Loza a los curas del arzobispado sobre la necesidad de rezar la oración a San José junto con el Santo Rosario. 20 de septiembre de 1889. Sección Gobierno. Serie Cartas pastorales, edictos y circulares. Circulares, años 1884-1903, caja 10, exp. 41, ficha 677. AHAG, Guadalajara, México.

\section{()ㅜ(1) $\$$}


Gabriel Amorth (1993), uno de los exorcistas más conspicuos de la Iglesia en la actualidad narra la tradición que explica los orígenes de esta oración y la forma del exorcismo utilizado por la Iglesia hasta mediados del siglo $\mathrm{xx}$ :

¿Cómo nació esta oración? Transcribo lo que publicó la revista Ephemerides Liturgicae, en 1955, págs. 58-59. El P. Domenico Pachenino escribe: "No recuerdo el año preciso. Una mañana el gran Pontífice León XIII había celebrado la S. Misa y estaba ayudando a otra, de acción de gracias, como de costumbre. De repente se le vio enderezar enérgicamente la cabeza, y fijar la vista intensamente en algo, encima de la cabeza del celebrante. Miraba fijamente, sin pestañear, pero con terror a la vez que maravillado, y cambiando de color y su fisonomía. Algo extraño le estaba ocurriendo. Finalmente, como volviendo en sí, dando un ligero pero enérgico golpe con la mano, se levanta. Se le ve dirigirse a su estudio privado. Sus familiares lo siguieron rápidamente y preocupados. Sumisamente le preguntan, Santo Padre, ¿se siente mal? ¿Necesita algo? Responde: Nada, nada. Después de media hora hizo llamar al Secretario de la Congregación de los Ritos y, dándole una hoja le ordena hacerla imprimir y hacerla llegar a todos los Obispos Ordinarios del mundo. ¿Qué contenía? La oración que recitamos al final de la Misa con el pueblo, con nuestra súplica a María y la invocación al Príncipe de las milicias celestiales, implorando a Dios que arroje al infierno a Satanás."

En este escrito se ordenaba también rezar tales plegarias de rodillas. Lo anterior, que había sido publicado también por el periódico La Semana del Clero, el 30 de marzo de 1947, no cita por cuáles fuentes obtuvo la noticia. Pero resulta insólita la forma como fue ordenado para recitar la oración que se envió a los Obispos Ordinarios en 1886. Como confirmación a cuanto escribe el P. Pechenino, tenemos el autorizado testimonio del Cardenal Nasalli Rocca quien, en su Carta Pastoral para la cuaresma, emanada [sic] en Bologna en 1946, escribe: "León XIII escribió él mismo esta plegaria. La frase (los demonios) que vagan por el mundo para la perdición de las almas tiene una explicación histórica, que nos fue comentada por su secretario particular, Mons. Rinaldo Angeli. León en verdad tuvo la visión de los espíritus infernales que pululaban sobre la ciudad eterna (Roma); y a partir de esta experiencia nació la oración que quiere que toda la Iglesia recite. Él decía esta oración con voz vibrante y potente; la oímos muchas veces en la Basílica vaticana. Además, escribió de su propia mano un exorcismo especial que aparece en el Ritual Romano [...]. Recomendaba estos exorcismos a los obispos y sacerdotes para

\section{(ㄷ)(1) $(3$}


que los rezaran continuamente en sus diócesis y parroquias. Él decía la oración varias veces durante el día” (Amorth, 1993, pp. 25-26).

Aun cuando esta anécdota no puede ser comprobada, pues no existen testimonios directos de León XIII al respecto y la fuente de la misma (la carta pastoral para la cuaresma de 1946 del cardenal y arzobispo de Bolonia Giovanni Battista Nasalli Rocca di Corneliano) es tardía, es significativo el hecho de su supervivencia en el imaginario de muchos fieles católicos y de exorcistas como Amorth incluso hasta la actualidad. El hecho es que en 1886, por disposición de León XIII, la oración a san Miguel arcángel fue enviada a todas las iglesias del mundo. El arzobispado de Guadalajara, mediante circular del 19 de octubre de 1886 dirigida a los curas párrocos de la diócesis, difundió las citadas preces para que llegaran "a noticia de todos los sacerdotes y fieles y se recen estas después de cada misa privada" remitiendo suficiente número de ejemplares con la indicación de que hubiera una en el altar de cada una de las iglesias. El texto de la circular señalaba la concesión por parte de León XIII de un jubileo extraordinario universal, así como la disposición de que "los sacerdotes de todo el mundo recitasen con el pueblo una deprecación que S.S. mismo ordenó, se ha servido últimamente modificar esta deprecación" y señala:

No cabe duda que la oración es la misteriosa arma que el Señor ha puesto en manos de su santa Iglesia y de los cristianos todos para librarse de las asechanzas del enemigo común, para extirpar el error, para vencer el poder de Satanás y para alcanzar del cielo las divinas gracias. [...] Al recitar como está mandado que lo hagáis las preces indicadas, por las cuales se ha servido S. S. conceder 300 días de indulgencias, os recomiendo que vuestro corazón se halle lleno de fe; que tengáis fija vuestra confianza en el Señor de los ejércitos y de las Potestades. ${ }^{22}$

Pedro Loza continuó promoviendo la difusión de esta oración en distintas ocasiones. El 21 de noviembre de 1890 Loza hizo una nueva edición del texto de las preces y el exorcismo recomendados por León XIII, y por su parte

${ }^{22}$ Carta circular del Gobierno Eclesiástico del Arzobispado de Guadalajara sobre la recitación de preces a San Miguel Arcángel. 19 de octubre de 1886. Sección Gobierno. Serie Cartas pastorales, edictos y circulares. Circulares, años 1884-1903, caja 10, exp. 15 ficha 652. AHAG, Guadalajara, México.

\section{()(1) $\$$}


recomendó de una manera especial su recitación frecuente a los sacerdotes diocesanos, mandando que se rezase "al terminar la misa privada por el Sacerdote celebrante y por el pueblo fiel que hubiere asistido al augusto Sacrificio, pidiéndose en una de esas oraciones, de manera especial, la protección y defensa del arcángel San Miguel, para que con su poderosa mano reprima y encadene a los espíritus malignos que vagan por el mundo, procurando la perdición de las almas" (Colección, 1891, pp. 393-396).

El 29 de septiembre de 1893 Loza publica una nueva circular (Colección, 1894, pp. 366-367) en la que vuelve a recomendar el rezo de dicha fórmula por parte de los sacerdotes de la diócesis, y es más explícito en las razones que lo mueven a ello:

En efecto, el Santo Padre, cuyo sapientísimo gobierno y extraordinaria piedad asombran al mundo, sabe, pues así lo da a entender, que en la época presente se verifica más que nunca lo que dice el Apóstol San Pedro: que el demonio anda como león rugiente en rededor de los hombres buscando a quien devorar. Sabe su Santidad que el espíritu del mal recrudece los ataques contra la humanidad y que legiones de ángeles malos vagan por el mundo, asedian la tierra, no en busca de otra cosa que de almas a quien perder para siempre en los infiernos. El influjo del demonio en el mundo, al presente, es muy marcado, y su táctica el día de hoy parece ser más familiar con los hombres (p. 366)

Las preces a San Miguel Arcángel y el exorcismo que en 1886 mandó publicar León XIII fueron ampliamente difundidos en su época en Guadalajara. Debido a que estas oraciones y el exorcismo fueron dados a conocer localmente a fines de dicho año, no alcanzaron a ser incluidos por el arzobispo Loza en su edición del Manual de Párrocos preparada por Luis R. Barbosa para los sacerdotes de su diócesis, que había sido impreso antes en Guadalajara en el mismo año. Sin embargo, sí fueron incluidas en el Manual para el uso del clero tapatío elaborado por Lauro Díaz Morales (1900) y aprobado por el arzobispo Jacinto Romo, sucesor de Pedro Loza, después que este muriera en noviembre de 1898. En una circular del 19 de julio de 1900 Jacinto Romo señalaba que dicho manual no sustituía al aprobado por Pedro Loza y que debía tenerse y conservarse un ejemplar de este en todos los templos habilitados de la arquidiócesis. ${ }^{23}$ Entre otras novedades, este nuevo manual sí

${ }^{23}$ Circular del arzobispo Jacinto López y Romo a los sacerdotes de la arquidiócesis sobre el nuevo manual de párrocos. 19 de julio de 1900. Sección Gobierno. Serie Cartas pastorales,

\section{()(1) $\$$}


incluía la oración a San Miguel Arcángel, acompañando a la última fórmula aprobada de exorcismo.

Es necesario detenerse en el análisis del Manual de Párrocos de 1886, pues el tratamiento que le da a los exorcismos es muy significativo. Desde el siglo Xvi los sacerdotes de Guadalajara hicieron uso de diversos manuales para sacerdotes que compendiaban las fórmulas y ritos de mayor uso aprobados por la Sagrada Congregación de Ritos en el Ritual Romano. ${ }^{24}$ Existió una gran variedad de manuales, impresos en diversas ciudades del mundo católico, que iban desde los dedicados a los encargados de atender comunidades indígenas, hasta los orientados a los sacerdotes ubicados en centros urbanos. Los ministros podían hacer uso de ellos siempre y cuando estuviesen aprobados en su respectiva diócesis. Para la diócesis tapatía el obispo Juan Ruiz de Cabañas (quien la gobernó de 1796 a 1824) se encargó de autorizar el uso de la obra del jesuita poblano Manuel Venegas (1680-1764), el Manual de Párrocos. Para Administrar Los Santos Sacramentos, y Las Demás Sagradas Funciones de su Ministerio, cuya primera edición fue impresa en México en 1731, y la segunda en Puebla, en $1783 .^{25}$

Hasta 1886 no existió un manual de párrocos o de sacerdotes propio de la arquidiócesis de Guadalajara, por lo que los sacerdotes tenían que hacer uso de otros manuales además del de Venegas, impresos en diversos sitios, y en ocasiones debían contar con dos o más de ellos para poder cubrir sus necesidades locales. Por ello, y con el fin de ordenar y unificar los usos litúrgicos en la arquidiócesis, Pedro Loza encargó al profesor de las cátedras de teología

edictos y circulares. Circulares, años 1884-1903, caja 10, exp. 95, ficha 734. AHAG, Guadalajara, México.

${ }^{24}$ Uno de los elementos más importantes de la liturgia de la Iglesia católica romana son los libros que contienen sus ritos, fórmulas, cantos y ceremonias, y cuyos contenidos son aprobados por la Sagrada Congregación de Ritos. En la antigüedad y en la Edad Media cada iglesia regional contaba con sus propios libros litúrgicos, pero entre el siglo ix y el Concilio de Trento en el siglo xVI, los contenidos se unifican y ordenan en seis libros: el Misal, el Breviario, el Ritual, el Pontifical, el Ceremonial de los Obispos y el Martirologio. Se permite que las iglesias locales hagan extractos, adaptaciones y resúmenes de los mismos de acuerdo con las costumbres y religiosidad locales. En especial, el Ritual Romano contiene las fórmulas oficiales, preces y ritos para la administración de los sacramentos, para las bendiciones, procesiones y exorcismos de la Iglesia. Fue impreso por primera vez en 1614 por el papa Paulo V, y lo corrigieron y adicionaron Benedicto XIV en 1752, León XIII en 1884, Pío XI en 1925, y más recientemente Juan Pablo II en 1998.

${ }^{25}$ Posteriormente la segunda edición fue reimpresa y añadida en México en 1811 (Venegas, 1811) por el también jesuita Juan Francisco López, y más tarde se reimprimió en México, en 1851.

\section{()(1) $\$$}


moral y ritos del Seminario Conciliar y cura de El Sagrario, don Luis R. Barbosa, ${ }^{26}$ que preparase un manual de párrocos acorde con las necesidades del arzobispado y conforme con las últimas disposiciones en materia de liturgia de la Sagrada Congregación de Ritos. El 12 de julio de 1886 Pedro Loza publicó una circular que se adjuntó como introducción a dicho manual en la que se prevenía a los párrocos y demás sacerdotes de la arquidiócesis que no usaren en lo sucesivo de otro manual en la administración de los sacramentos y demás funciones sagradas, debiendo por lo mismo tenerse y conservarse un ejemplar en todas y cada una de las Iglesias del arzobispado (Barbosa, 1886, p. 3). Este manual es, en lo esencial, una nueva versión del manual de Venegas, actualizada y cuidadosamente expurgada de varios comentarios innecesarios.

Las partes específicas más extensas del manual de Barbosa (1886) son las dedicadas a las Bendiciones (Título xI, pp. 326-390), a las Procesiones (Título xiI, pp. 391-443), a los Exorcismos de los obsesos por el demonio (Título XIII, pp.443-477), así como el Apéndice (pp. 487-629) correspondiente a la instrucción sobre los recién convertidos a la fe y otras bendiciones no contenidas en el Ritual Romano. Estas últimas resultan particularmente interesantes, pues son una muestra de algunas bendiciones utilizadas en la diócesis de acuerdo con los usos locales, como las bendiciones de las vías férreas, instalaciones del telégrafo, edificios, estandartes procesionales, entre otras.

Es importante entender que este manual no contiene fórmulas exclusivas para la región. Se trata de una compilación de fórmulas y ritos contenidos en el Ritual Romano o aprobados por la Sagrada Congregación de Ritos para uso universal de la Iglesia, como el ya mencionado de Venegas. Las fórmulas de exorcismo que contiene ya estaban incluidas en otros manuales impresos de la época. Lo que sí es propio de este manual es la selección específica de contenidos de acuerdo con las necesidades locales o regionales, así como los comentarios explicativos que acompañan al texto y que buscan ordenar y normar las conductas, tanto de los sacerdotes como de los fieles.

Si bien el manual de 1886 de Barbosa sigue en lo esencial la estructura y contenidos del manual de Venegas (1811), presenta algunas diferencias importantes. Una de las más notables es la parte referente a los exorcismos,

${ }^{26}$ Fray Ángel Tiscareño (1909, p. 260) señala que Luis del Refugio Barbosa fue originalmente un religioso francisano y ex guardián del convento y cronista del Colegio de Propaganda Fide de Zapopan, quien ante la exclaustración tuvo que secularizarse, y fue después cura de El Sagrario Metropolitano de Guadalajara y teólogo consultor del Ilmo. Sr. Loza.

\section{()ㅜ(1) $(3$}


y a la manera de visualizar la intervención del demonio en la sociedad. Los dos manuales, el de Venegas y el de Barbosa, dedican amplios apartados a describir el ritual de exorcismo; sin embargo, Venegas, un ilustrado del siglo XVIII, no consideraba que la presencia del demonio fuese un problema, como lo señala en los siguientes párrafos que son la introducción al ritual de exorcismo, y que fueron eliminados en la versión de Barbosa (1886):

Desde que se conquistó este Reyno [sic], y apareció en él la Portentosa Imagen de Nuestra Señora de Guadalupe, no se ha visto jamás en él algún endemoniado, lo que en otras partes suele ser muy frequente [sic]. Sin embargo, porque nada de lo contenido en el Ritual Romano falte en este Manual, y para que sus Rúbricas puedan servir de dirección para formar un juicio prudente, siempre que se sospechare de alguno, que ha incurrido en semejante desgracia, se ha tenido por bien no omitir el modo de exorcizar los obsesos.

Por los muchos escándalos que cada día se originaban de la ignorancia de los Exorcistas, han quitado los Obispos a todos los Eclesiásticos la Jurisdicción, y facultad de exercitar [sic] su potestad, sin examen, aprobación, y licencia dada por ellos mismos, o por sus Vicarios in scriptis. [...] Limitase en esta fórmula la licencia de exorcizar a seis meses, que son los que corren desde primero de Noviembre de un año, a primero de Mayo del año siguiente, porque la experiencia ha enterado, que los demonios, irritados con su expulsión de los cuerpos por los Exorcismos, han conmovido los vientos, y levantado tempestades de granizo, i piedra, con que han arruinado los campos, que por mayo reverdecen, y florecen, y hasta primero de Noviembre están pendientes muchos de sus frutos.[...] Aunque este ministerio puede exercerlo [sic] el Exorcista legítimamente ordenado, pero la común práctica de la Iglesia, es, que lo exerza [sic] el Sacerdote, cuya eminente dignidad le eleva sobre los Ángeles, y sobre los demonios, y el solo es conveniente que haga las muchas bendiciones, que además de los Exorcismos, deben hacerse en esta función, si no es que tal vez sea menester preferirle otro de inferior orden por su acreditada pericia, y destreza en el ministerio (Venegas, 1811, pp. 598-599).

Venegas adopta una posición ilustrada desde la que no encuentra motivos para aplicar el exorcismo en tierras de Nueva España. Como él mismo lo indica, se incluye el rito del exorcismo sólo por motivos ilustrativos, y señala que sólo los exorcistas acreditados pueden realizar el ritual. En el manual de Barbosa (1886), en cambio, la actitud ante la presencia del demonio es diferente, pues de entrada se elimina esta introducción sin mayor explicación. De

\section{(1)(1) $\$$}


hecho, tampoco se incluye la advertencia puesta por Venegas (1811) de que los exorcistas requieren de una autorización especial del obispo para poder ejercer como tales, lo que abre la puerta a que muchos sacerdotes puedan realizar el rito cuando lo consideren pertinente, sin necesidad de recurrir en todos los casos al permiso del obispo. Las páginas dedicadas al exorcismo por Barbosa compilan todas las notas esenciales concernientes al rito que pone Venegas a lo largo de las distintas partes del ritual; sin embargo, Barbosa elimina las notas y comentarios racionalistas que Venegas incluye a lo largo del texto. Tómense como ejemplo los siguientes párrafos dedicados a la expulsión de objetos del cuerpo del obseso, y la forma en que es tratado un mismo problema por ambos autores:

Manual de Venegas (1811, p. 609)

Mande al demonio [se refiere al exorcista] que le declare si le detiene en el cuerpo del obseso alguna operación mágica, o algunos signos o instrumentos maléficos; y que si el obseso los hubiere tomado por la boca, los vomite; y que si están en otra parte, descubra dónde están: y hallados quémense.

Aunque ha habido mugeres [sic] tan diestras, que haviéndose [sic] fingido maleficiadas, se han dado maña para vomitar, después de los Exorcismos, cosas muy extrañas, para hacer creíble su maleficio, y lograr sus depravados fines, sin embargo la Rubrica insiste, en que hay maleficios verdaderos, o instrumentos externos, en que se afianza el pacto que hace el hechicero con el demonio, para que mientras duraren, esté obligado el maligno espíritu a hacer mal: y una vez destruidos, cese la obligación, o desista de hacerlo. Estos instrumentos, o signos, unas veces son solamente aparentes, o unas meras ilusiones, pues acabados los exorcismos, y expelido
Manual de Barbosa (1886, p. 446)

Mande al demonio [se refiere al exorcista] que le declare si le detiene en el cuerpo del obseso alguna operación mágica, o algunos signos o instrumentos maléficos; y que si el obseso los hubiere tomado por la boca, los vomite; y que si están en otra parte, descubra dónde están: y hallados quémense.

[Eliminado] 
el demonio, los que parecían ser cuchillos, agujas, herraduras, clavos, valas [sic], marañas de cabellos, etc. no eran más que salivas, y humores flemáticos, y pituitosos del estómago, arrojados por la boca: otras veces son verdaderos traídos prontamente de otra parte, y presentados a los ojos como sí en la realidad los vomitase el obseso: otras se los introduce verdaderamente en el cuerpo, y realmente los vomita: $y$ otras en fin los esconde, y guarda el hechicero. Vomítense, pues, ó hállense en alguna parte estos signos, o instrumentos, en que consiste el maleficio deben quemarse, y de ninguna manera es lícito hacer de ellos otro uso. [...].

Amoneste también el Exorcista al obseso, que le manifieste todas sus tentaciones.

Amoneste también el Exorcista al obseso, que le manifieste todas sus tentaciones.

Como se aprecia en ambos textos, Venegas, como buen ilustrado del siglo XVIII, pone en duda muchas de las manifestaciones demoniacas observadas en los exorcismos. En cambio, el laconismo del texto de Barbosa expresa una fe absoluta en el fenómeno que se observa. En el texto de Barbosa no se pone en duda ni la existencia del maleficio ni la presencia del demonio. Si bien ambos textos recomiendan de la misma manera ser cautelosos, pues muchas manifestaciones que se consideran demoniacas son producto de la enfermedad, en el texto de Venegas se manifiesta un mayor escepticismo ante el fenómeno de la posesión. Consideramos que el texto de Barbosa pone de relieve la idea de la presencia real y concreta del demonio en la vida diaria de los fieles de Guadalajara. Como ya se señaló, el manual publicado por Jacinto Romo en 1900 contenía las preces en latín a san Miguel arcángel y una versión abreviada del ritual de exorcismo (Díaz Morales, 1900, pp. CXIII-CXXII) para que pudiese ser utilizado por los sacerdotes de la diócesis cada vez que lo requirieran, conservando vigentes todas las disposiciones y fórmulas contenidas en el manual de 1886. El único comentario que acompaña al texto en latín viene al final del rito, y señala que "El Ilmo. y Rvmo. Sr. Arzobispo de esta Arquidiócesis recomienda

\section{()(1) $(9$}


de una manera especial, a los Sres. Sacerdotes, la recitación frecuente de este Exorcismo" (Díaz Morales, 1900, p. cxxiI).

\section{A MANERA DE CONCLUSIÓN}

Como se ha visto en este trabajo, a lo largo del siglo xix la Iglesia católica desarrolló un discurso escatológico en el que el demonio adquirió un papel central como explicación de las condiciones permanentes de crisis de la sociedad que enfrentaron la Iglesia y los creyentes en la época. Guadalajara fue un campo propicio para la recepción de este discurso, no sólo porque desde la época colonial existía una fuerte religiosidad basada en la confianza en Dios y sus santos, sino porque el apego a la tradición católica configuró un habitus $^{27}$ dentro del campo religioso de Guadalajara, retroalimentado por un ambiente familiar en el que se fomentaba la piedad junto con otras virtudes cívicas, y que predispuso a los fieles a apegarse a la práctica de sus devociones religiosas. Este habitus, que se reforzó con la presencia de este discurso escatológico, podría ser identificado, grosso modo, con lo que Agustín Yáñez (1945, p. 169) llamó “el clima espiritual de Jalisco”, y que caracterizó el ambiente religioso en que vivieron inmersos los fieles de Guadalajara, quienes percibían un ambiente de constante ataque contra la Iglesia y la sociedad que sólo podía ser combatido de manera eficaz mediante el ejercicio de la piedad. En suma, consideramos que este discurso escatológico es uno de los factores que explican la permanencia y continuidad de la devoción religiosa en una época caracterizada por el laicismo, la secularización y el anticlericalismo. Así, la devoción fue una forma de dar respuesta a los miedos que planteaba la amenaza permanente del demonio a la sociedad.

${ }^{27}$ Bourdieu (2007) señala que los condicionamientos asociados a una clase particular de condiciones de existencia producen habitus, sistemas de disposiciones duraderas y transferibles, estructuras estructuradas predispuestas a funcionar como estructuras estructurantes, es decir, como principios generadores y organizadores de prácticas y de representaciones que pueden ser objetivamente adaptadas a su meta sin suponer el propósito consciente de ciertos fines ni el dominio expreso de las operaciones necesarias para alcanzarlos, objetivamente "reguladas" y "regulares" sin ser para nada el producto de la obediencia a determinadas reglas, $y$, por todo ello, colectivamente orquestadas sin ser el producto de la acción organizadora de un director de orquesta (p. 86).

\section{()(1) $\$$}




\section{LISTA DE REFERENCIAS}

Amorth, G. (1993). Narraciones de un exorcista (Presentación del padre Cándido Amantini). México: Publicaciones Kerygma.

Barbosa, L. R. (1886). Manual de párrocos para administrar los Santos Sacramentos y ejecutar las demás sagradas funciones de su ministerio, [...]. Anotado [...] por el presb. D. Luis R. Barbosa. Guadalajara: Imprenta, litografía y lib. de Ancira y Hno.

Bourdieu, P. (2007). El sentido práctico (Trad. de Ariel Dilon). Buenos Aires: Siglo XXI Editores Argentina.

Calendario nigromántico para el año 1858 (1857). México: Imprenta de M. Murguía, portal del Águila de Oro.

Carbajal López, D. (2014). ¿Un "patronato ritual”? La autoridad civil en la liturgia en México durante la primera mitad del siglo xix. En J. C. Casas y P. Mijangos (coords.), Por una iglesia libre en un mundo liberal. La obra y los tiempos de Clemente de Jesús Munguía, primer arzobispo de Michoacán (1810-1868) (pp. 23-55). México: Universidad Pontificia de México/El Colegio de Michoacán.

Cid, G. (2014). "Las señales de los últimos tiempos”. Laicidad y escatología en el pensamiento católico hispanoamericano del siglo XIX. Hispania Sacra, LXVI(133), 179207. DOI: $10.3989 /$ hs. 2013.050

Colección de documentos eclesiásticos publicada por la Arquidiócesis de Guadalajara. Tomo II. Comienza el 8 de enero de 1878 y concluye el 22 de diciembre de 1879 (1879). Guadalajara: Imprenta de N. Parga.

Colección de documentos eclesiásticos publicada por la Arquidiócesis de Guadalajara. Tomo IV. Comienza el 8 de enero de 1883 (1886). Guadalajara: Imprenta de N. Parga. (En la portada aparece erróneamente 1883 como fecha de impresión).

Colección de documentos eclesiásticos publicada por la Arquidiócesis de Guadalajara. Tomo VI. Comienza el 8 de enero de 1889 y concluye el 22 de diciembre de 1891 (1891). Guadalajara: Antigua Tipografía de N. Parga.

Colección de documentos eclesiásticos publicada por la Arquidiócesis de Guadalajara. Tomo VII. Comienza el 8 de enero de 1892 y termina el 22 de diciembre de 1894 (1894). Guadalajara: Antigua Tipografía de N. Parga.

Collantes, J. (2009). La fe de la Iglesia católica. Las ideas y los hombres en los documentos doctrinales del Magisterio ( $4^{\mathrm{a}}$ ed.). (Colección BAc 446). Madrid: Biblioteca de Autores Cristianos.

Connaughton, B. (1992). Ideología y sociedad en Guadalajara (1788-1853). México: UNAM/Consejo Nacional para la Cultura y las Artes.

Delumeau, J. (1997). La religión y el sentimiento de seguridad en las sociedades de antaño. En H. Gortari y G. Zermeño (eds.), Historiografía francesa. Corrientes te-

\section{()(1) $(3$}


máticas y metodologías recientes (pp. 17-35). México: Centro Francés de Estudios Mexicanos y Centroamericanos/CIESAs/IIH-UnAM/Instituto Mora/Universidad Iberoamericana.

Delumeau, J. (2012). El miedo en Occidente (siglos XIV-XVIII). Una ciudad sitiada (Trad. de Mauro Armiño, revisada por Francisco Gutiérrez). México: Taurus.

Díaz Morales, L. (1900). Manual eclesiástico extractado del Ritual Romano por disposición del Ilmo. y Rmo. Sr. Arzobispo D. Jacinto López, para el uso del V. Clero del Arzobispado de Guadalajara. Guadalajara: Imp. Ancira Hno. A. Ochoa.

Eliade, M. (1978). Mito y realidad ( $3^{\mathrm{a}}$ ed.) (Trad. de Luis Gil). Barcelona: Guadarrama. Foucault, M. (1981). La naturaleza humana: justica contra poder. En F. Elders (ed.), La filosofía y los problemas actuales (pp. 145-212). Madrid: Fundamentos.

Guerra, F.-X. (1992). Modernidad e independencias. Ensayos sobre las revoluciones hispánicas. Madrid: MAPFRE.

Lafaye, J. (2013). De la historia bíblica a la historia crítica. El tránsito de la conciencia occidental. México: Fondo de Cultura Económica.

León XII [Annibale Francesco Clemente Melchiorre Girolamo Nicola Sermattei della Genga] (1839). Bula de nuestro santísimo padre el señor León XII por la cual [...] prohíbe de nuevo y para siempre jamás todas las sociedades secretas llamadas de francmasones o cualquiera de otro nombre (Reimpr. de la Bula emitida el 13 de marzo de 1825). México: Imprenta de Galván a cargo de Mariano Arévalo.

Maistre, J. de (2003). Considerations on France [1797] (Ed. y trad. de Richard A. Lebrun, introd. de Isaiah Berlin). Cambridge, Inglaterra: Cambridge University Press.

Martínez, H. A. (1992). La catedral de Guadalajara. Guadalajara: s. e.

Olveda Legaspi, J. (1997). Culto y religiosidad en la Guadalajara colonial. Guadalajara: Instituto Cultural Ignacio Dávila Garibi.

Olveda Legaspi, J. (2016). Propuesta para periodizar al siglo XIX. Ponencia presentada en el Seminario Taller de Investigación de El Colegio de Jalisco, Zapopan, México.

Staples, A. (2009). El miedo a la secularización o un país sin religión. México 18211859. En P. Gonzalbo Aizpuru, A. Stapples y V. Torres Septién (eds.), Una historia de los usos del miedo (pp. 237-290). México: Centro de Estudios Históricos/Universidad Iberoamericana-El Colegio de México.

Taylor, W. B. (2010). Shrines and miraculous images. Religious life in Mexico before the reforma. Albuquerque: University of New Mexico Press.

Tiscareño, Á. de los D. (1909). Nuestra Señora del Refugio patrona de las misiones del Colegio Apostólico de Nuestra Señora de Guadalupe de Zacatecas. Zacatecas: Talleres de Nazario Espinosa.

\section{()(1) $(2$}


Tovar, R. (bajo el seudónimo de "Un Católico") (1859). Crímenes de la demagojia. El Colegio Apostólico en Zacatecas. Guadalajara: Tipografía del gobierno, a cargo de Luis P. Vidaurri.

Un Amigo de la Verdad (pseudónimo) (1882). El Diablo y los masones. En Colección de documentos eclesiásticos publicada por la Arquidiócesis de Guadalajara. Tomo III. Comienza el 8 de agosto de 1880 y concluye el 22 de diciembre de 1882. Guadalajara: Imprenta de N. Parga.

Velasco Toro, J. (2007). Matiana, mística del imaginario y "voz de ultratumba”. Ulúa. Revista de Historia, Sociedad y Cultura, 10. Recuperado de http://revistas.uv.mx/index.php/ulua/issue/view/UL\%C3\%9AA\%2010/showToc

Venegas, M. (1811). Manual de párrocos. Para administrar los Santos Sacramentos, y las demás sagradas funciones de su ministerio [...] Añadido, [...] por el P. Juan Francisco López. México: Imprenta de Doña María Fernández de Jáuregui.

Wright-Rios, E. (2014). Searching for Madre Matiana. Prophecy and popular culture in modern Mexico. Albuquerque: University of New Mexico Press.

Yáñez, A. (1945). El clima espiritual de Jalisco. Occidente (4).

\section{OTRAS FUENTES}

AHAG Archivo Histórico del Arzobispado de Guadalajara, México. 